\title{
Isolated solitary recurrent skull metastasis in papillary thyroid carcinoma
}

\author{
Dukhabandhu Naik, ${ }_{1}^{1}$ Felix K Jebasingh, ${ }^{2}$ Krishna Prabhu, ${ }^{3}$ Nihal Thomas ${ }^{4}$
}

'Department of Endocrinology, Christian Medical College, Vellore, Tamil Nadu, India 2Department of Endocrinology, Christian Medical College, Vellore, Tamil Nadu, India ${ }^{3}$ Department of Neurosurgery, Christian Medical College, Vellore, Tamil Nadu, India ${ }^{4}$ Department of Endocrinology, Diabetes and Metabolism, Christian Medical College, Vellore, Tamil Nadu, India

Correspondence to Dr Nihal Thomas, nihal_thomas@yahoo.com

Accepted 7 April 2018

\section{DESCRIPTION}

A 38-year-old woman presented with history of painless expansible swelling in the right frontoparietal region since 2 years and rapidly increasing in size since the last 6 months. She was initially evaluated in another centre and was diagnosed as a meningioma. She had a history of total thyroidectomy and radioiodine ablation for a non-metastatic papillary carcinoma thyroid (PCT) in the year 2008. She was on a regular follow-up between 2009 and 2012 and during that period her serum thyroglobulin and whole-body iodine scan was normal. However, she was lost to follow-up but she had continued her suppressive doses of thyroxin.

Her T1-weighted MRI showed a lobulated expansile, intensely heterogeneously enhancing lesion arising from the right frontoparietal region (size $77 \times 52 \times 88 \mathrm{~cm}$ ) (figure 1$)$. The fluorodeoxyglucose-positron emission tomography (PET) CT scan showed a metabolically active expansile soft tissue lesion (standard uptake values, 64) with lytic area and bony spicules (figure 2). There is no uptake in the thyroid bed or any other region, thereby suggesting solitary skeletal metastases. Her serum thyroglobulin level was $2260 \mathrm{ng} / \mathrm{mL}$, hence a final diagnosis of PCT with isolated solitary skeletal metastasis was considered. She was advised I-131 whole body scan (total body scan)

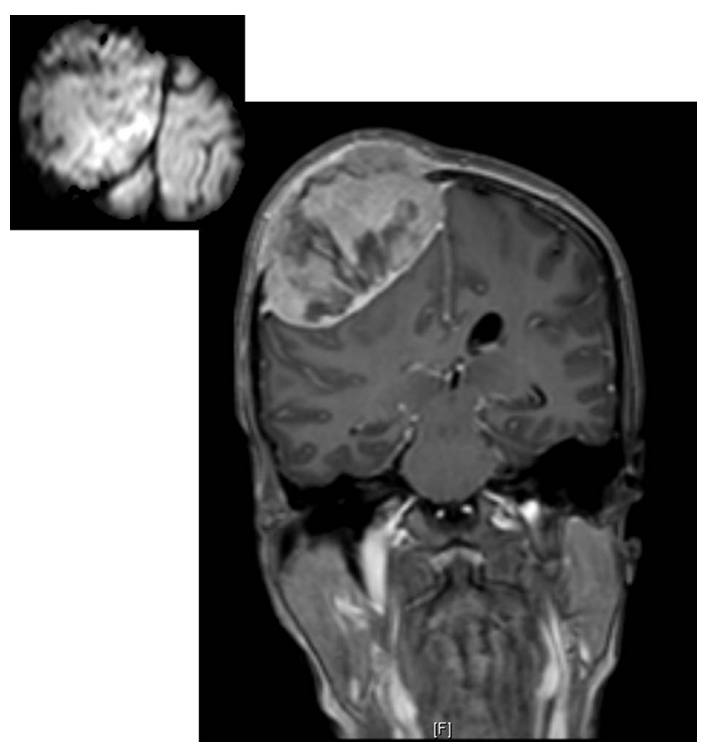

Figure 1 T1-weighted MRI with contrast showing a lobulated expansile, intensely heterogeneously enhancing lesion arising from the right frontoparietal region (size $77 \times 52 \times 88 \mathrm{~cm})$.

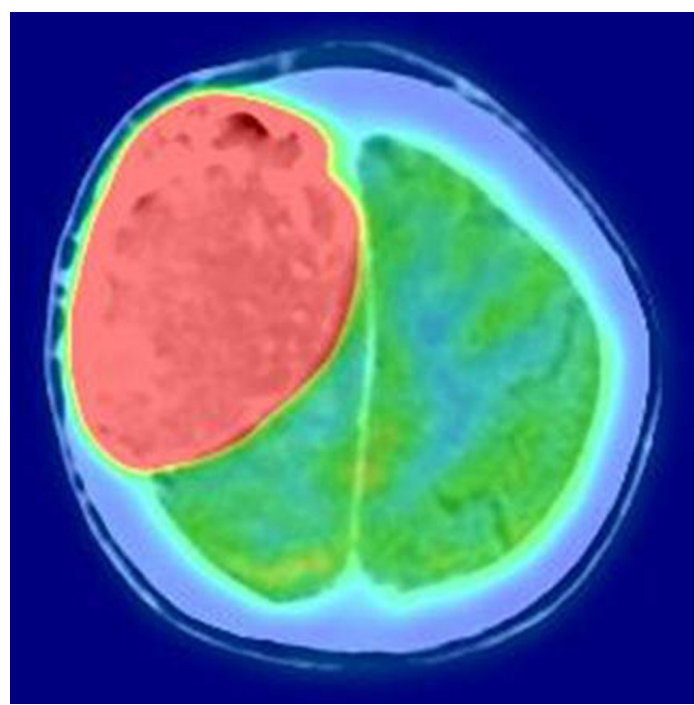

Figure 2 The fluorodeoxyglucose-positron emission tomography (FDG-PET) CT scan showing a metabolically active expansile soft tissue lesion (standard uptake values (SUV), 64) with lytic area and bony spicules.

4 weeks after stopping thyroxine; however, she did not come back for follow-up.

Skeletal metastasis is seen in 1\%-7\% of patients with PCT at diagnosis. ${ }^{1}$ Isolated solitary metastatic skull recurrence is rare in post-treatment cases of PCT. PET scan or an I-131 whole body scan is helpful in detecting the extent of bone metastasis in differentiated thyroid carcinoma. ${ }^{2}$ Excision of a metastatic skull lesion followed by I-131 radioiodine and thyroxine replacement is the ideal line of treatment.

Learning points

- Metastatic lesions should be considered in the differential diagnosis of an expansible solitary skull lesion in patients with a history of thyroid carcinoma.

- The delay in presentation is common among patients with differentiated thyroid carcinoma because of the asymptomatic nature of the metastatic lesion.

- Early diagnosis of a metastatic lesion has a significant impact on a decision-making in treatment and prognosis in patients with differentiated thyroid carcinoma.

Contributors DN and FKJ prepared the manuscript. KP was involved in the management of the patient. DN, FKJ, KP and NT edited and finalised the manuscript. 
Images in...

Funding The authors have not declared a specific grant for this research from any funding agency in the public, commercial or not-for-profit sectors.

Competing interests None declared.

Patient consent Obtained.

Provenance and peer review Not commissioned; externally peer reviewed.

(c) BMJ Publishing Group Ltd (unless otherwise stated in the text of the article) 2018. All rights reserved. No commercial use is permitted unless otherwise expressly granted.

\section{REFERENCES}

1 Durante C, Haddy N, Baudin E, et al. Long-term outcome of 444 patients with distant metastases from papillary and follicular thyroid carcinoma: benefits and limits of radioiodine therapy. J Clin Endocrinol Metab 2006;91:2892-9.

2 Iwata M, Kasagi K, Misaki T, et al. Comparison of whole-body 18F-FDG PET, 99mTcMIBI SPET, and post-therapeutic 131I-Na scintigraphy in the detection of metastatic thyroid cancer. Eur J Nucl Med Mol Imaging 2004;31:491-8.

3 Borsò E, Boni G, Mazzarri S, et al. Disseminated bone metastases from occult thyroid cancer effectively treated with debulking surgery and a single dosimetry-guided administration of radioiodine. Rev Esp Med Nucl Imagen Mol 2015;34:111-5.

Copyright 2018 BMJ Publishing Group. All rights reserved. For permission to reuse any of this content visit

http://group.bmj.com/group/rights-licensing/permissions.

BMJ Case Report Fellows may re-use this article for personal use and teaching without any further permission.

Become a Fellow of BMJ Case Reports today and you can:

- Submit as many cases as you like

- Enjoy fast sympathetic peer review and rapid publication of accepted articles

- Access all the published articles

Re-use any of the published material for personal use and teaching without further permission

For information on Institutional Fellowships contact consortiasales@bmjgroup.com

Visit casereports.bmj.com for more articles like this and to become a Fellow 